extracellular volume contraction on renal reabsorption of bicarbonate in fetal lambs. Pediatr Res 11:649-655

38. Stephenson G, Hammet M, Hadaway G, Funder JW 1984 Ontogeny of renal mineralocorticoid receptors and urinary electrolyte responses in the rat. Am J Physiol 247:F665-F671

39. Iwamoto HS, Oh W, Rudolph AM 1985 Renal metabolism in fetal and newborn sheep. In: Jones CT, Nathanielsz PW (eds) The Physiological Development of the Fetus and Newborn. Academic Press, Orlando, pp 37-
40

40. Elinder G, Aperia A 1982 Renal oxygen consumption and sodium reabsorption during isotonic volume expansion in the developing rat. Pediatr Res 16:351353

41. Aperia A, Larsson L 1984 Induced development of proximal tubular NaKATPase, basolateral cell membranes and fluid reabsorption. Acta Physiol Scand 121:133-141

42. Igarashi Y, Aperia A, Larsson L, Zetterstrom R 1983 Effect of betamethasone on Na-K-ATPase activity and basal and lateral cell membranes in proximal tubular cells during early development. Am J Physiol 245:F232-F237

43. Schwartz GJ, Evan AP 1984 Development of solute transport in rabbit proximal tubule. III. Na-K-ATPase activity. Am J Physiol 246:F845-F852

( mal tubule. Ill. Na-K-ATPase activity. Am J Physiol 246:F845-F852

-

\title{
Announcement
}

\section{Annual Meeting} The American Pediatric Society and The Society for Pediatric Research will hold the meetings on April 27-April 30, 1987 at the
Disneyland Hotel, Anaheim, CA.

For information, contact: Audrey Brown, M.D., Secretary-Treasurer, American Pediatric Society, SUNY, Health Science Center at Brooklyn, Dept. of Pediatrics, Box 49, 450 Clarkson Avenue, Brooklyn, NY 11203 (212)270-1692 OR Mrs. Debbie Wogenrich, Office of the Executive Secretary, Society for Pediatric Research, Dept. of Pediatrics, University of New Mexico School of Medicine, Albuquerque, NM 87131 (505)277-6629 